\title{
Comment on "A Federalist Explanation \\ of Municipal Elections"
}

Rodney E. Hero, University of Colorado, Boulder

While efforts at theoretical advancement in the study of U.S. urban polities and of federalism certainly are to be welcomed, such efforts bear heavy conceptual and theoretical burdens. These burdens include the basic and longstanding ambiguity of the concept of "federalism" itself, along with the relative dearth and questionable persuasiveness of previous "theories" of federalism and of urban politics.

The central significance of federalism in the U.S. political system long has been widely recognized, but a universally agreed upon definition and conceptualization has remained elusive (Rothman 1978). Many debates continue to focus on the "real meaning" of federalism -- at the Founding, historically, and into the present (e.g., Diamond 1985; Elazar 1984, 1-9). Indeed, political and policy debates often center on the very issue of federalism's meaning and implications. By extension, the status and role of the various elements in the federal system, perhaps especially those not mentioned in the U.S. constitution -- i.e., municipal governments -- have been difficult to incorporate theoretically.

The Young and Stein article is a valuable effort to extend certain existing theorizing about federalism's policy significance to formulate a "general theory" of voting behavior in municipal elections. There is little question that federalism, or the particular version of it developed in the present article, plays a role in explaining municipal election issues and outcomes. But the general premise and the specific application of the theory presented in this article are, I think, more limited than is acknowledged. Here I will, first, offer comments on the "general theory" presented, arguing that the theory is in fact much more particular than is portrayed by Young and Stein, and, second, I will suggest briefly that even the limited general theory offered is not tested adequately.

A "federalist explanation" of municipal elections may say both a great deal, and, perhaps at the same time, very little. It is partly a matter of what is meant by federalism. Young and Stein's notion of federalism emphasizes dependence, more particularly, economic dependence. They argue that the place of cities within the larger political economy -- specifically, their functional responsibility -- requires that elected officials campaign on, and voters respond to, calls for economic 
development and avoidance of redistributive policies (of either a material or nonmaterial nature). Beyond this, the particular meaning of federalism that underlies this article is not, in my view, well clarified. Federalism can imply various levels of independence, interdependence, and dependence of governments, based on one's emphasis. Because of the particular emphasis in the Young and Stein article, its title is somewhat misleading in that theirs is more a discussion of functional responsibility in the intergovernmental system, and from the particular angle of political economy, at that. Moreover, the various forms of (economic) dependence are not exhaustive of what is meant by federalism. The U.S. political system is not solely, as the political economy perspective would have it, a "commercial republic." As a number of writers have stressed, there are also a number of moral, normative, and symbolic issues that are major concerns of government, and state and local governments historically have been the central polities in this latter respect. In overlooking that, Young and Stein treat as irrational behavior that which readily can be explained from other perspectives.

Young and Stein appropriately remind us of and underscore federalism's pervasive, if often nebulous, influence in the U.S. political system. At the same time it should be noted that every election in the United States, at any level and at any point in time, is at least partly explicable by federalism if we take a broader view of federalism as (1) a functional division of labor and (2) some degree of authority of local, state, and national governments to structure their electoral processes. Even a casual reading of the present article indicates a number of (internal) qualities of Houston politics and elections that are principally determined by non-national factors, i.e., that illustrate the authority that municipal governments have in structuring their elections. These include the scheduling of elections in odd-numbered years, separate from state and/or national elections; limited mayoral powers and (two-year) terms; and nonpartisan rather than partisan elections. The latter may be particularly important, given that party identification generally is seen as the strongest predictor of individual vote choice. In cities where partisanship is a part of the formal electoral process, such as Chicago, or where partisanship has been an informal aspect of elections (see Hero and Beatty 1989), the kinds of political economic factors stressed by Young and Stein may be significantly modified.

A further problem with Young and Stein's argument is that it is not linked to important theoretical, conceptual, and policy developments that have followed from Peterson's (1981) work. Clarke (1987), among others, has shown that while a "developmental bias" may be strong, it does not mean that there is only one way to pursue such goals. Thus, one might expect all mayoral candidates broadly to emphasize developmental policy, but to distinguish themselves in the regard of particular programs. Perhaps this and similar issues and patterns influenced the 1985 Houston mayoral elections, but the article is quite sketchy on these matters. Not enough evidence of issues and themes in the 1985 mayoral election is presented to ascertain emphases in campaigns. 
Welch, the challenger to incumbent Whitmire, may have emphasized the gay rights issue because both he and Whitmire essentially were alike on economic development concerns (which would at least partly support the Young and Stein thesis). This could have necessitated taking pains to distinguish himself from the incumbent by interjecting issues of municipal police/regulatory power. In any case, it seems doubtful that Welch's introduction of the gay rights issue into the campaign showed a "fundamental misunderstanding" of local elections (as Young and Stein assert), given Welch's experience as a former five-term mayor and head of the Chamber of Commerce for 11 years, which indicates a competent understanding of local politics and the place therein of economic development. Also, their thesis does not account for why Whitmire openly supported the gay rights proposal in the first place (her later distance from the issue notwithstanding). That local governments are polities, with significant powers to act on behalf of the morals and well-being of their citizens, rather than just political economies, makes these matters more understandable.

Also, the paper overlooks the strong "intergovernmentalization" of public policy, even in the wake of various efforts by the Reagan administration (among others) to "sort out" governmental responsibilities. Yet, Peterson, the source of much of this paper's theoretical underpinning, has acknowledged -- in fact, questioned -- the rationality of the extensive involvement of the national government in developmental policies. But Peterson and others have recognized that much of this national attention to developmental policies arises from the particular, topocratic (territorially-based) federal structure of Congress. Peterson also has noted the extent to which, and the circumstances under which, urban (municipal) governments effectively implement redistributive policies (Peterson, Rabe \& Wong 1986). Indeed, while the concluding sentences of the article anticipate detractors who might consider the article "antiquated" because of its 1985 data, a substantially more serious problem is that the theorizing is ahistorical and acontextual, even in relation to the body of literature that it is most clearly linked to.

Similarly, there is a questionably selective use of previous work. Ironically, one of the better discussions indicating the ahistorical and acontextual nature of the preceding article can be drawn from Stein himself (1989). Stein contends that a city's formative building phase appears crucial in influencing the types and levels of governmental programs that are undertaken and maintained. Southwestern (and southern) cities are newer and post-industrial compared to cities in the northeast and northcentral U.S. The growth period of southwestern cities was dominated by a native, white middle class (unlike northeastern cities, where non-native eastern Europeans were prominent during the formative period). This native, white middle-class dominance led to a consensual, nonpartisan city politics that, in turn, led to a minimal level of social programs and a narrow range of governmental services. And that history of minimal social services of southwestern cities continues to this day, as does the northeastern cities' tendency toward a more 
extensive range of governmental services (Stein 1989).

Also, Elkin, whose thinking prominently influences the Young and Stein thesis, has pointed to important variations in cities' political economies. Entrepreneurial cities have in common "a relatively unimpeded alliance at work composed of public officials and local businessmen, an alliance that is able to shape the workings of political institutions so as to foster economic growth." Entrepreneurial political economies, according to Elkin (1987), have been dominant in southwestern cities in the post-World War II period. Pluralist and federalist political economies are found most commonly in large northeastern and midwestern cities, respectively. Entrepreneurial political economies differ from pluralist and federalist ones in that the "behavior of public officials in the entrepreneurial version is not as much shaped by the building of electoral organizations and political coalitions" (Elkin 1987: 81, emphasis added).

Houston also is noted for not exercising zoning powers, and thus may be a particularly poor choice upon which to build a general theory. If cities' abilities to influence labor and capital are limited by technological and other developments, a city's self-imposed unwillingness to shape land-use makes it particularly unique. At the same time, Houston and other Texas cities, because of state laws, have powers of annexation that are relatively distinct in the U.S. And, of course, there are a variety of other ways in which cities in different states have more or less authority and power. However, political economy explanations, including the one presented here, generally have not accounted adequately for the tremendous and significant variation of state-local relations across the U.S.

\section{II}

Beyond serious problems with the theory's generalizability, how well does the evidence support the thesis? Here, several concerns and questions will be raised. First, the article doesn't control adequately for incumbency advantage, which may be critical to the present findings. It is claimed that the undecided vote went overwhelmingly to Whitmire because of issue positions, but her familiarity (incumbency) also may have played a role.

Regarding concepts and their operational measures, several points can be noted. Are a candidate's ability to "lead [a] city's economic recovery, and her/his ability to promote general economic growth and development necessarily one and the same, as the article treats them? To ask a general question about a mayor's "performance of her duties over the last four years" also is problematic. It is possible that a citizen's evaluation may be linked to performance of duties that are not related to economic development; but the authors seem to assume that the evaluation is primarily, if not entirely, linked to developmental activities. Also, the "four years" in the survey question incorporates two electoral terms in sequence; it is not clear whether citizens make that distinction or not. Is it possible that a voter might have viewed Whitmire negatively during one term and positively 
during the other? If so, what might be the consequences of this for the larger argument that Young and Stein put forth?

Using citizens' positions on the gay rights issues seems a questionable test of the (extended) political economy thesis. It is not clear that that issue appropriately falls within the political economy argument that is being tested in the article. It is not, strictly speaking, part of the political economy argument as developed by Peterson and others, and to include it as such is probably an unwarranted theoretical extension. Permitting such an extension for the moment, the gay rights issue might as well be viewed as part of the allocational, rather than the redistributive, arena. The issue deals with "the hiring of city employees," and, in my understanding of the Peterson argument, such issues are economically neutral. Whatever impact the gay rights measure may or may not have had on vote choice, then, may be irrelevant to the theory that is supposed to have been tested.

While some additional concerns might be posed, suffice it to say that concept measurement and related problems undermine the cogency of the evidence presented, perhaps severely so.

However, it is encouraging that here and elsewhere scholars of the caliber of Young and Stein (see Stein, 1990) are seeking to advance and examine theories of federalism and urban politics. Whatever shortcomings such work has had to this point, they are to be applauded for their efforts.

\section{REFERENCES}

Clarke, Susan E. 1987. More Autonomous Policy Orientations:An Analytic Framework. In Clarence N. Stone and Heywood T. Sanders, eds., The Politics of Urban Development. Lawrence, KS: University Press of Kansas.

Diamond, Martin. 1985. What the Framers Meant By Federalism. In Laurence J. O'Toole, ed., American Intergovernmental Relations. Washington, DC: Congressional Quarterly Press.

Elazar, Daniel J. 1984. American Federalism: A View from the States. New York: Harper and Row.

Elkin, Stephen L. 1987. City and Regime in the American Republic. Chicago: University of Chicago Press.

Hero, Rodney E. and Kathleen M. Beatty. 1989. The Elections of Federico Pena as Mayor of Denver. Social Science Quarterly 70: 300-310.

Peterson, Paul E. 1981. City Limits. Chicago: University of Chicago Press. , Barry G. Rabe and Kenneth K. Wong. 1986.When Federalism Works. Washington, DC: Brookings.

Rothman, Rozann. 1978. The Ambiguity of American FederalTheory. Publius 8: 103-122.

Stein, Robert M. 1989. Market Maximization of Individual Preferences and Metropolitan Municipal Service Responsibility. Urban Affairs Quarterly 25: 86-116. . 1990. Economic Voting for Governor and U. S. Senator: The Electoral Consequences of Federalism. Journal of Politics 52: 29-53. 
236| Rodney E. Hero

Young, Cheryl D. and Robert M. Stein. 1992. A Federalist Explanation of Municipal Elections. Midsouth Political Science Journal 13: 211-229. 